\title{
Antioxidant activity study and total phenolic determination of leaf extracts of Ximenia americana L. (Olacaceae) an anti- tumor plant used traditionally in Mali.
}

\author{
Madani MARIKO1,2*, Serigne Omar SARR ${ }^{1}$, Amadou DIOP1, Issoufou Ali Modi', Blaise \\ Dackouo²,Yérim Mbagnick DIOP1 \\ ${ }^{1}$ Laboratory of Analytical Chemistry and Bromatology, University Cheikh Anta DIOP, B.P. 5005, \\ Dakar, Senegal \\ 2Laboratory of Analytical Chemistry, Faculty of Pharmacy, University of technical Sciences and Technology, B.P. \\ 1805, Bamako, Mali \\ *Corresponding author email: marikomadani@gmail.com (00223 761105 38)
}

Original submitted in on 10 August 2016. Published online at www.m.elewa.org on $31^{\text {st }}$ October 2016 http://dx.doi.org/10.4314/jab.v106i1.5

\begin{abstract}
Objectives: Most of the currently used anticancer drugs are highly toxic and expensive. There is a continuing need to identify new drugs that are more effective and less toxic. Plants are an important source of potentially useful compounds for the development of new anticancer drugs.

Methodology and results: This work was used to study the antioxidant activity of two extracts of Ximenia americana (Tallow wood) by the methods of ABTS ${ }^{\circ+}$ and DPPH using ascorbic acid as standard. It determined the rate of total phenolic in these extracts by the Folin-Ciocalteu (FC) method using Gallic acid as standard. The extracts inhibited the absorbance of $\mathrm{DPPH} \cdot$ depending concentrations attesting that extracts of this plant contains antioxidants. The calculated $\mathrm{IC}_{50}$ are 2.78 and $4.05 \mu \mathrm{g} / \mathrm{mL}$ for ethanolic and aqueous extracts respectively with DPPH . Phenolic rates are $43.10 ; 41 ; 2 \mathrm{mg} / \mathrm{mL}$ respectively for alcoholic and aqueous extracts. Conclusion and application of results: Future studies can be oriented on the isolation and identification of compounds involved in an anti-cancerous activity. The knowledge of this plant could be used to build an appropriate conservation strategy for this specie.
\end{abstract}

Keywords: Medicinal plants, ABTS++, DPPH, Total phenolic, Cancer

\section{INTRODUCTION}

Cancer is a dreadful disease and any practical solution in combating this disease is of paramount importance to public health (Sharma et al., 2011). Traditional medicine that is most ancient way of curing diseases remains the main avenue of developing new drugs for treating deadly diseases such as cancer. Medicinal plants are the major constituents of traditional medicine and are the sources of many conventional therapeutic agents.
For instance, the anticancer agents, vinblastine and vincristine were isolated from the plant Catharanthus roseus commonly called Madagascar periwinkle (Ngulde et al., 2015).Natural products from plants have been valuable sources for anticancer drug discovery. A screening program was initiated that identified many antibacterial antifungal, antiviral, antiparasitic, and other pharmacologically active substance activities in higher plants (Oskoueian et 


\section{Mariko et al. J. Appl. Biosci. $2016 \quad$ Antioxidant activity study and total phenolic determination of leaf}

extracts of Ximenia americana L. (Olacaceae) an anti-tumor plant used traditionally in Mali.

al., 2009; Li et al., 2015). Ximenia americana L. (Figure 1) is widely used in folk medicine in West Africa to treat various disorders such as inflammation, pain, fever, diarrhoea, wounds and intoxications (Onifade et al., 2011; Kidik et al., 2015). Different parts of the plant are used as infusion, maceration or decoction. Published scientific reports of the biological activities of the plant are scanty and include antitoxic, anticancer and antimicrobial (Maikai et al., 2016; Onifade et al., 2011). According to a recently published analysis by American authors of the 175 compounds currently used in cancer chemotherapy, $14 \%$ are natural and $28 \%$ correspond to a modified natural product (Butler and Newman, 2008). Of the $58 \%$ who are formally purely synthetic, $11 \%$ contain a natural pharmacophore and $4 \%$ contain not only natural but also have a pharmacophore competitive inhibition with respect to the natural substrate (Monneret, 2010). One study reported that the use of medicinal plants relates

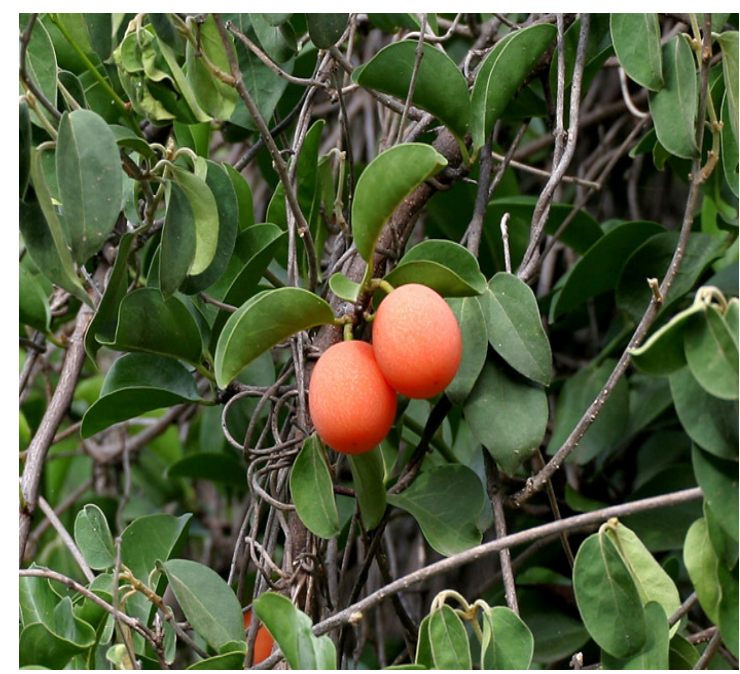

generally $28-60 \%$ of cancer patients in France (Chabosseau and Derbré, 2016). Renewed interest in traditional pharmacopeias is increasing worldwide most especially among African people who are becoming reliant on herbal medicines for their health care needs. This is because medicinal plants are more accessible and affordable (Alzeer et al., 2014; Maikai et al., 2015). Therefore, it seems important to study the antioxidant activity of extracts of medicinal plants as Ximenia americana, plant used in traditional treatment of cancer in Africa (Ngulde et al., 2015; Sharma et al., 2011). Thus this work begins in a vast process of valorisation of the medicinal herbs used in the traditional treatment of cancer among those are Ximenia americana (Sanogo, 2001). It aims to study the antioxidant activity of two extracts of this plant by the methods of $\mathrm{ABTS}^{\cdot+}$ and $\mathrm{DPPH}{ }^{\cdot}$ and to determine the rates of total phenolic in these extracts.

Figure 1: Photography stems with leaves and fruits (Ximenia americana).

\section{MATERIALS AND METHODS}

Plant material: The aerial parts of Ximenia americana (leaves) were supplied as powdered and dried. It was harvested from Bamako the capital of Mali. It was identified by the Head of Botany Department of the Faculty of Pharmacy of Bamako.

Preparation of plant extract: Ethanolic and aqueous extracts of Ximenia americana, were prepared according the method used by Sarr et al., (2015). The plant powder (500 grams) was extracted with $1 \mathrm{~L}$ of ethanol at $90^{\circ}$ for ethanolic extraction and $1 \mathrm{~L}$ of distillated water at $90^{\circ} \mathrm{C}$ for water extraction. The extract solution was concentrated to dryness in a rotary evaporator. After this operation, the crude extract was conserved at $4^{\circ} \mathrm{C}$ until use for absorbance measurements where the required concentrations were prepared with extracts (Sarr et al., 2015).

Antioxidant activity determinations (ABTS++): The $\mathrm{ABTS}^{++}$assay was done according the following method. 


\section{Mariko et al. J. Appl. Biosci. $2016 \quad$ Antioxidant activity study and total phenolic determination of leaf extracts of Ximenia americana L. (Olacaceae) an anti-tumor plant used traditionally in Mali.}

The stock solutions were prepared by dissolving $38.4 \mathrm{mg}$ of $\mathrm{ABTS}^{++}$and $6.75 \mathrm{mg}$ potassium persulfate each with $2.5 \mathrm{~mL}$ of distillated water. The working solution was then prepared by mixing the two solutions (ABTS++ and potassium persulfate) completed to $10 \mathrm{~mL}$ and allowed to react for 12 hours at room temperature in the dark. This solution was diluted by mixing of methanol to obtain an absorbance of 0.70 at $734 \mathrm{~nm}$ (Nanometer). For each assay, $2 \mathrm{~mL}$ of alcohol extract, aqueous extract, and ascorbic acid at different concentration (2, 3, 4 and $5 \mu \mathrm{g} / \mathrm{mL}$ ) were allowed to react with $2 \mathrm{~mL}$ of working solution diluted and left for 2 minutes in dark. The absorbance was measured at $734 \mathrm{~nm}$ using the spectrophotometer (Mariko et al., 2016).

Antioxidant activity determinations (DPPHo): The DPPH $\bullet$ assay was done according the following method. The stock solution was prepared by dissolving $4 \mathrm{mg}$ DPPH' with $100 \mathrm{~mL}$ of ethanol for 12 hours in a dark. This solution was diluted by mixing of ethanol to obtain an absorbance of 0.90 at $517 \mathrm{~nm}$. For each assay, $0.8 \mathrm{~mL}$ of alcohol extract, aqueous extract, and ascorbic acid at different concentration $(2,3,4$ and $5 \mu \mathrm{g} / \mathrm{mL})$ were allowed to react with $3.2 \mathrm{~mL}$ of the $\mathrm{DPPH}$. solution in dark for 30 minutes. After the absorbance was measured at $517 \mathrm{~nm}$ using the spectrophotometer (Mariko et al., 2016).

Percent inhibition estimation (PI): All the measurements of absorbance were made in triplicates. The ability to inhibit absorbance of $\mathrm{ABTS}^{++}$or DPPH' radical was calculated by the following formula (1):

\section{RESULTS}

Antioxidant activity determinations (DPPH' test): In this work the extracts and ascorbic acid inhibited the absorbance of DPPH' depending on the different concentrations of each solution. The alcohol extracts presented higher activity compared to aqueous extract. However, the standard presented higher activity than alcohol and aqueous extracts. Percentages of inhibition (PI) of the two extracts are very different to those of ascorbic acid used as a standard. The PI of the high concentrations of ascorbic acid and extracts to reach $100 \%$ values. With concentrations extracts tested, all the curves show a nearly non-linear domain with the depletion of extracts and standard concentrations (Figure 2 and 3 ). Antioxidant activity determinations (ABTS+' test): The alcohol and aqueous as well as the standard extracts inhibited the absorbance of $\mathrm{ABTS}^{++}$depending on the different concentrations of each solution. The alcohol extracts presented higher activity compared to aqueous extract. Percentages of inhibition (PI) of extracts are very different to those of ascorbic acid used as a standard in
$P I=\frac{\Delta 1-\Delta 2}{A 1}: 100$

$A_{1}$ : absorbance of $\mathrm{ABTS}^{++}$or $\mathrm{DPPH}$ solution; $\mathrm{A}_{2}$ : absorbance of $A B T S \cdot+$ or DPPH - solution after adding the extract (Padmanabhan et al., 2012).

Inhibitory concentration estimation $\left(\mathrm{IC}_{50}\right)$ : The $\mathrm{IC}_{50}$ value is estimated using the following formula (2) used by Mariko et al., (2016):

$$
\mathrm{y}=\mathrm{a} * \mathrm{x}+\mathrm{b} \quad \text { IC50 }=\frac{(50-\mathrm{b})}{\mathrm{a}}
$$

Total phenolic determination: The total phenolic of ethanolic or aqueous extracts were determined by the Folin-Ciocalteu (FC) method using Gallic acid as a standard $(5-25 \mu \mathrm{g} / \mathrm{mL})$ by modifying the protocol of Anvitha, (2015). Different concentrations of standard as well as the extracts $(5-25 \mu \mathrm{g} / \mathrm{mL})$ were taken and $1 \mathrm{~mL}$ of Folin-Ciocalteu reagent (1:1 v:v dilution) was added 3-5 minutes after $2.0 \mathrm{~mL}$ of saturated sodium carbonate was added and the mixture was allowed to stand for 45 minutes under dark condition. Absorbance of standard and samples were read at $670 \mathrm{~nm}$ using a spectrophotometer. The concentration of total phenolic was expressed in terms of $\mathrm{mg} / \mathrm{mL}$ GAE: Gallic acid equivalence (Anvitha et al., 2015; Bassène, 2012).

this $\mathrm{ABTS}^{++}$test. The PI of standard is higher than extracts $\mathrm{PI}$ according concentrations. The trend of IP is almost similar in both cases according to different concentrations of extracts (ABTS'+ and DPPH' test). Curves show a non-linear domain with the depletion of extracts concentrations (Figure 2 and 4 ).

Percent inhibition calculated: Antioxidant activities measured in ethanolic and aqueous extracts obtained using $\mathrm{ABTS}^{++}$and $\mathrm{DPPH} \cdot$ assays were measured three times to test the reproducibility of the assays. In general it is observed that the lowest concentration to the highest PI increase and varies. Percent inhibition have values ranging from 60.46 to $96.37 \%$ (ABTS'+); 31.91 to $89.77 \%$ (DPPH' test) with the standard and the extracts tested. The inhibitory activity of each extract, is greater with $\mathrm{ABTS}^{+*}$ has DPPH . Absorbance is inversely proportional to the PI (formula 1). The calculated PI saw strong fluctuations with concentrations of the standard than extracts. 


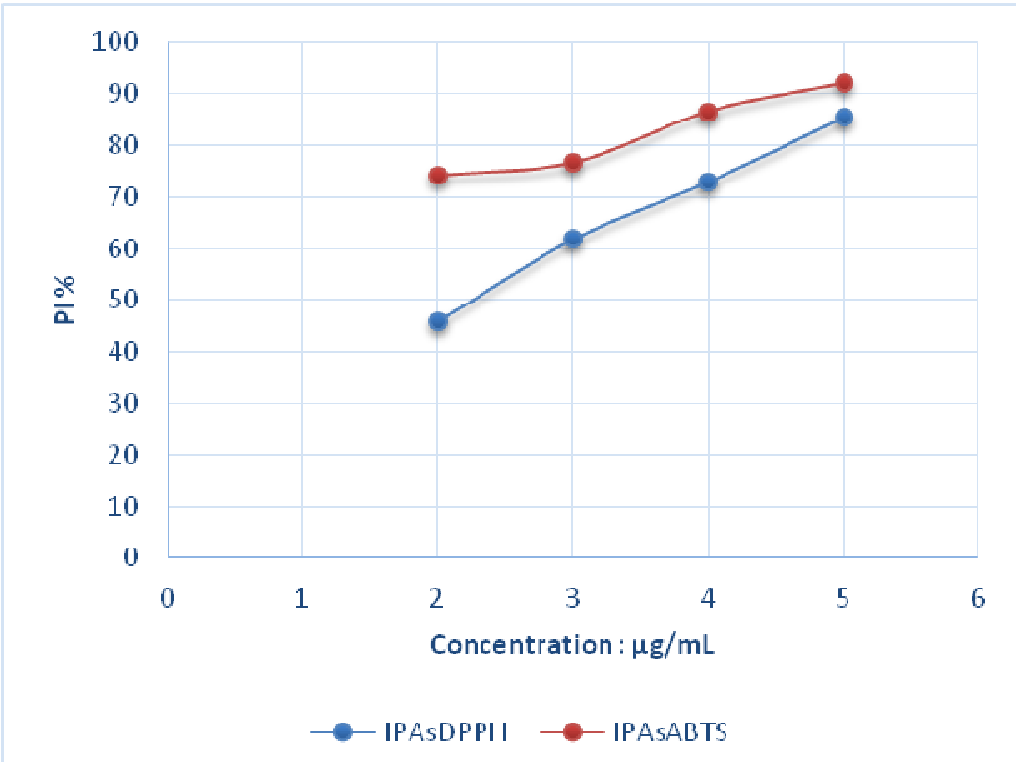

Figure 2: PI of the free radical $\mathrm{ABTS}{ }^{++}$and $\mathrm{DPPH} \cdot$ by ascorbic acid.

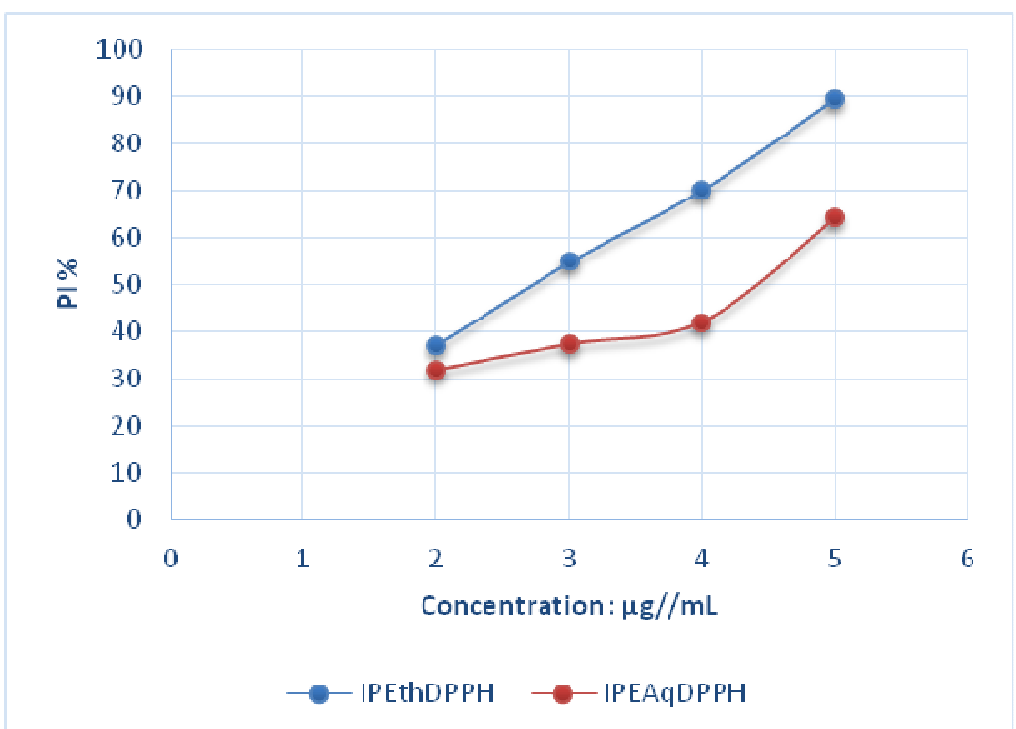

Figure 3: PI of the free radical DPPH• by extracts. 


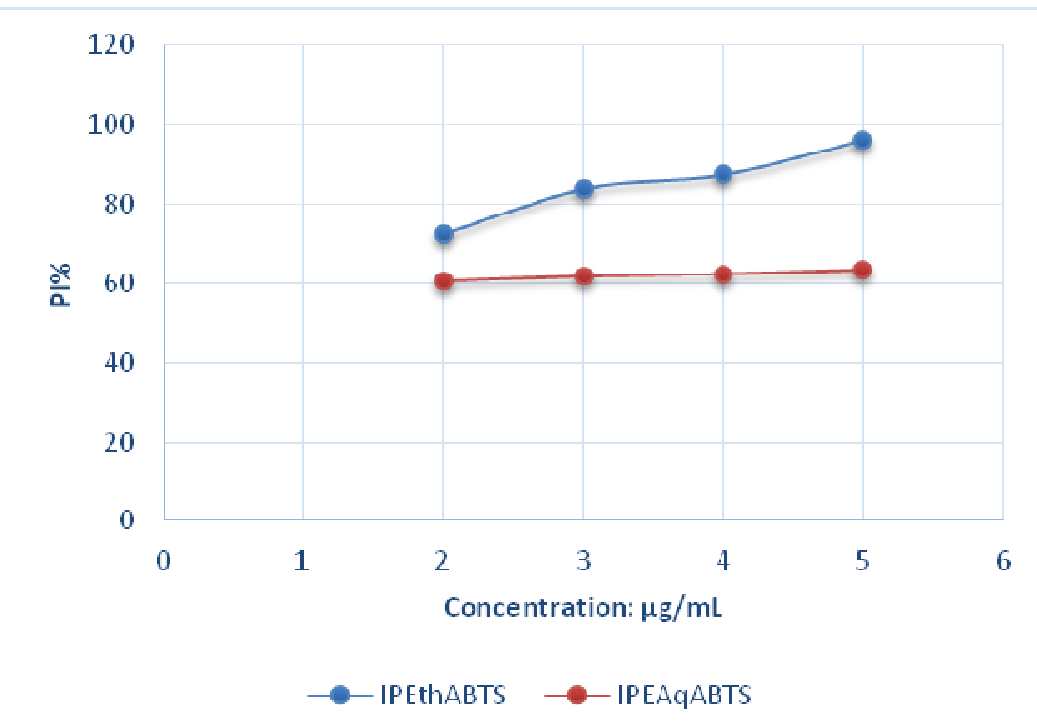

Figure 4: PI of the free radical ABTS++ by extracts.

Study of the reaction kinetic: It was also performed by reading the absorbance kinetics mode to see the behaviour of the mixture (extract and DPPH') during the reaction. The course of the curves shows a progressive decrease in absorbance with the reaction time. The speed of this reaction is more pronounced at the beginning and becomes very small after 30 minutes (normal time of incubation in the dark). Visual exam of these curves shows that the reaction becomes very low without stabilized even beyond the time of incubation ( 30 minutes). This behaviour of these curves is related to the decrease of the concentrations in the reading vessel. Figures 5, 6 and 7 show three slices readings include: 0 10 ; $10-20$ and $20-50$ minutes.

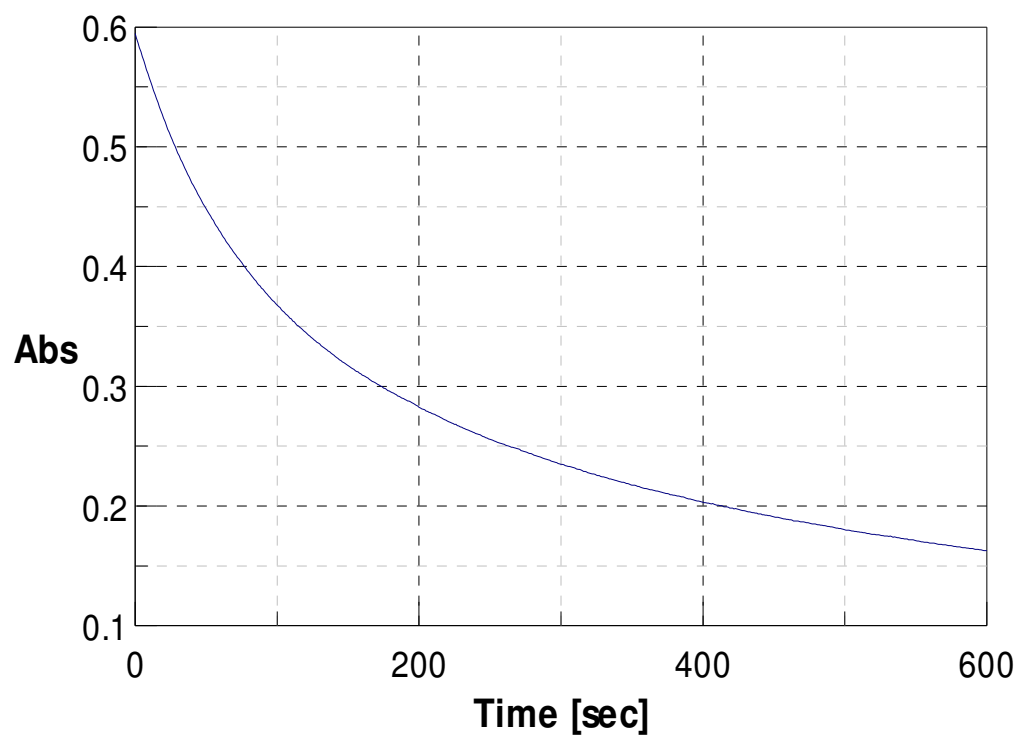

Figure 5: Spectra of the reaction kinetic of DPPH' and alcohol extracts $(5 \mu \mathrm{g} / \mathrm{mL} 0-10$ minutes). 


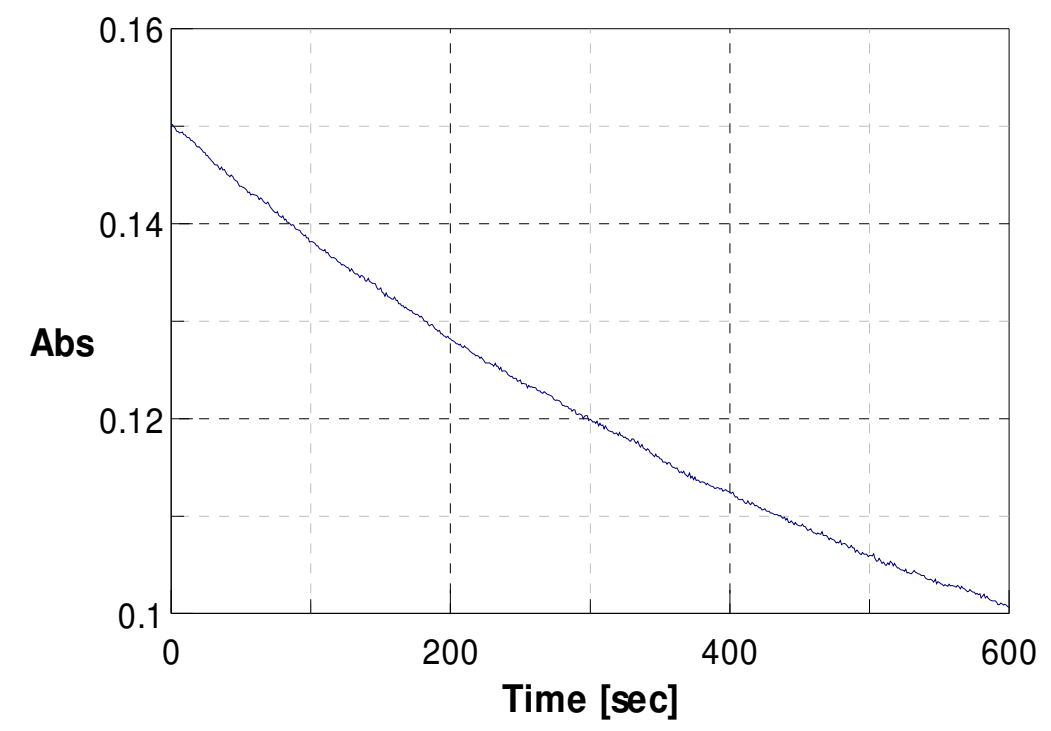

Figure 6: Spectra of the reaction kinetic of $\mathrm{DPPH} \cdot$ and alcohol extracts $(5 \mu \mathrm{g} / \mathrm{mL} 10-20$ minutes).

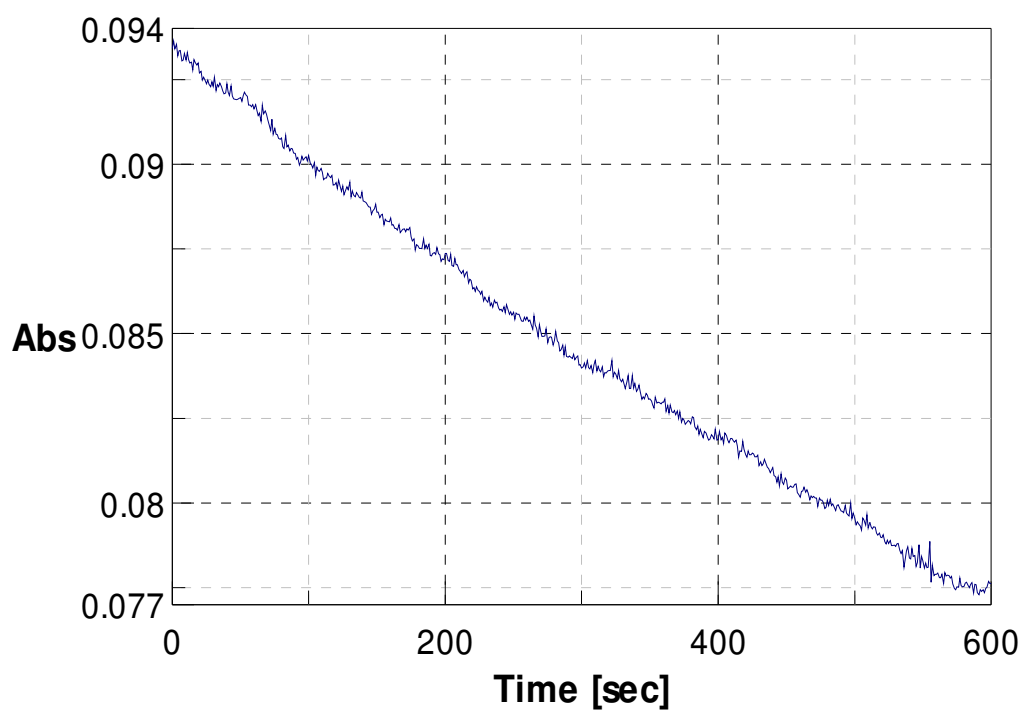

Figure 7: Spectra of the reaction kinetic of DPPH· and alcohol extracts $(5 \mu \mathrm{g} / \mathrm{mL} 20-30$ minutes).

Inhibitory concentration $\left(\mathrm{IC}_{50}\right)$ value of different antioxidant activity: Using the formula (2) the calculated $\mathrm{IC}_{50}$ are 2.78 and $4.05 \mu \mathrm{g} / \mathrm{mL}$ for ethanolic and aqueous extracts respectively with DPPH' test. These results show that the alcoholic extract is more active than the aqueous extract.

\section{DISCUSSION}

Most of the currently used anticancer drugs are highly toxic, expensive, and resistance mechanisms pose a significant problem (Alzeer et al., 2014). There is a continuing need to identify new drug candidates that are
Total phenolic determination: The extracts of Ximenia americana leaves contained phenolic compounds. Phenolic rates are 43.10 and $41.22 \mathrm{mg} / \mathrm{mL}$ respectively for ethanolic and aqueous extracts.

more effective, widely available and less toxic. Plants extracts are an important source of potentially useful compounds for the development of new anticancer drugs (Alzeer et al., 2014). In the present work Inhibition, 


\section{Mariko et al. J. Appl. Biosci. $2016 \quad$ Antioxidant activity study and total phenolic determination of leaf extracts of Ximenia americana L. (Olacaceae) an anti-tumor plant used traditionally in Mali.}

percentages (PI) obtained showing values over $90 \%$ for maximum concentration $(5 \mathrm{~m} \mu \mathrm{g} / \mathrm{mL})$ for each leaf extract of Ximenia americana. However in a study conducted by Sarr et al., (2015), the percentages of inhibitions were calculated over $90 \%$ that for $150 \mu \mathrm{g} / \mathrm{mL}$ with extracts and fractions of Aphania senegalensis and Saban senegalensi. This shows that Ximenia americana contains more antioxidant substances compared to those two plants namely Aphania senegalensis and Saban senegalensi (Sarr et al., 2015). The alcohol extract has the most important antioxidant activity with $2.78 \mu \mathrm{g} / \mathrm{mL}$ value of $\mathrm{IC}_{50}$. In opposite aqueous extract showed a lower activity with $4.05 \mathrm{mg} / \mathrm{mL}$ as $I_{50}$. Nevertheless in a study both calculated $\mathrm{IC}_{50}$ are less important compared to the $\mathrm{IC}_{50}$ of the standards 0.97 and $2.28 \mu \mathrm{g} / \mathrm{mL}$ respectively for quercetin and ascorbic acid in the same study $I \mathrm{C}_{50}$ were $2.56 \mu \mathrm{g} / \mathrm{mL}$ and $20.83 \mu \mathrm{g} / \mathrm{mL}$ for ethanolic and aqueous extracts of Prosopis africana, where aqueous extract showed a lower activity than the aqueous extract of Ximenia americana (Mariko et al., 2016). The extracts of Ximenia americana leaves contained phenolic

\section{CONCLUSION}

The expensive cost of the treatments offered by modern medicine, and more often troublesome side effects, is the main limitations encountered during processing. These limits may justify the search for new therapeutic approaches with substances in the natural state of traditional medicine to treat cancer. Thus medicinal plants targeted anticancer as Ximenia americana, can provide

\section{REFERENCES}

Abdullah A, H, Mohammed A, S, Abdullah R, Mirghani M, E, S, Al-Qubaisi M, 2014. Cytotoxic effects of Mangifera indica L. kernel extract on human breast cancer (MCF-7 and MDA-MB-231 cell lines) and bioactive constituents in the crude extract. Complement. Altern. Med., 14(199): 3310.

Alzeer J, Vummidi BR, Arafeh R, Rimawi W, Saleem H, Luedtke N, W, 2014. The influence of extraction solvents on the anticancer activities of Palestinian medicinal plants. J. Med. Plants Res., 8(8):408-415.

Anvitha N, R, Monnanda S, N, 2015. Phytochemical Screening Total phenolic content and Radical Scavenging Activity of Leaf and Flower Extracts of Strobilanthes heyneanus Nees. Int. J. Plants Med., 108: 665-670.

18.Bassène $E, 2012$. Initiation à la recherche sur les substances naturelles: Extraction - Analyse - compounds these rates were 43.10 and $41.22 \mathrm{mg} / \mathrm{mL}$ respectively for alcoholic and aqueous extract. Values calculated are slightly higher than those found in a total phenolic determination study of leaf extracts of Prosopis africana. This published scientific reported that total phenolic rate was $34.19 \mathrm{mg} / \mathrm{mL}$ for the ethanol extract and $33.02 \mathrm{mg} / \mathrm{mL}$ for the aqueous extract (Mariko et al., 2016). In a comprehensive study on the phytochemical contents and biological activities of the methanolic extract from different parts of Jatropha curcas was conducted. The extracts of different plant parts contained various levels of total phenolic respectively $38.8 \pm 2.14 \mathrm{mg} / \mathrm{mL}$; $8.0 \pm 0.15 \mathrm{mg} / \mathrm{mL}$ for leave and root (Oskoueian et al., 2011; Thomas et al., 2016). These results are also lower than those obtained in this work. This means that the Jatropha curcas contains less of phenolic compounds than Ximenia americana, which also contains less than the Prosopis africana. Phenolic and flavonoid compounds, which occur ubiquitously in plants, are known to possess a variety of biological activities (Oskoueian et al., 2011; Laouali et al., 2014; Satapathy et al., 2015).

an adequate response to the complex problem of cancer. In addition, the knowledge of this plant could be used to build an appropriate conservation strategy for this specie. Future studies can be oriented on the isolation and identification of compounds involved in an anti-cancerous activity.

Essais Biologiques. Presses Universitaires de Dakar, Dakar, p.100.

Butler M, S, Newman D, J, 2008. Mother Nature's gifts to diseases of man: the impact of natural products on anti-infective, anticholestemics and anticancer drug discovery. Prog. Drug Res., 65:3-44.

Chabosseau S, Derbré S, 2016. Cancer du sein : recommendations sur l'usage de la phytothérapie. Actual. Pharm., 552:45-48.

Kidik P, M, C, Ngene J, P, Ngoule C, C, Mvogo O, P, B, Ndjib R, C, Dibong S, D, Mpondo M, E, 2015. Caractérisation des plantes médicinales à flavonoïdes des marchés de Douala (Cameroun). Int. J. Biol. Chem. Sci., 9(3): 14941516.

Laouali A, Guimbo I, D, Larwanou M, Inoussa M, M, Mahamane A, 2014. Utilisation de Prosopis africana (G. et Perr.) Taub dans le sud du 


\section{Mariko et al. J. Appl. Biosci. $2016 \quad$ Antioxidant activity study and total phenolic determination of leaf}

extracts of Ximenia americana L. (Olacaceae) an anti-tumor plant used traditionally in Mali.

département d'Aguié au Niger : les différentes formes et leur importance. Int. J. Biol. Chem. Sci., 8(3): 1065-1074.

Li Y, Zhou S, Li J, Sunb Y, Hasimu H, Liu R, Zhanga T, 2015. Quercetin protects human brain microvascular endothelial cells from fibrillar $\beta$ amyloid1-40-induced toxicity. Acta. Pharm. Sin., $5(1): 47-54$.

Maikai B, V, Maikai V, A, 2015. Effects of treatment with fraction IV extract of Ximenia americana on the survival rate, packed cell volume and total plasma proteins of Trypanosoma congolense infected mice. J. Parasitol. Vector Biol., 7(5):101107.

Mariko M, Sarr S, O, Issoufou M, A, Dackouo B, 2016. Antioxidant activity and phytochemical study of leaf extract of Prosopis africana (Guill \& Perr Taub) an anti-tumor plant used traditionally. J. Chem. Pharm. Res., 8(6):521-525.

Monneret C, 2010. Current impact of natural products in the discovery of anticancer drugs. Ann. Pharm. Fr., 68:218-232.

Nassr-Allah A, A, Aboul-Enein A, M, Aboul-Enein $\mathrm{K}, \mathrm{M}$, Lightfoot D, A, Alan E, S, C, Hany A, 2009. Anticancer and anti-oxidant activity of some Egyptian medicinal plants. J. Med. Plant Res., 3(10):799-808.

Ngulde S, I, Sandabe U, K, Hussaini I, M, 2015. Ethnobotanical survey of anticancer plants in Askira/Uba local government area of Borno State, Nigeria. Afr. J. Pharm. Pharmacol., 9(5):123-130.

Onifade A, O, Ouedraogo M, Ouedraogo M, Zongo F, E, Kafando E, Lompo M, Guissou I, P, 2011. Acute toxicity and anti-inflammatory activity of aqueous ethanol extract of root bark of Ximenia americana L. (Olacaceae). Afr. J. Pharm. Pharmacol., 5(7): 806-811.

Oskoueian E, Abdullah N, Saad W, Z, Omar R, Ahmad S, Kuan W, B, Zolkifli N, A, Hendra R, Ho Y, W, 2011. Antioxidant, anti-inflammatory and anticancer activities of methanolic extracts from Jatropha curcas Linn. J. Med. Plant. Res., 5(1): 49-57.

Padmanabhan $\mathrm{P}$, Jangle $\mathrm{S}, \mathrm{N}$, Evaluation of DPPH Radical Scavenging Activity and Reducing Power of Four Selected Medicinal Plants and Their Combinations. Int. J. Pharm. Sci. Drug Res., 4(2): 143-146.

Sanogo N, N, 2011. Recueil d'espèces végétales ligneuses en voie de disparition et d'importance particulière dans la région de Bamako. Bamako, Jamana, p.57.

Sarr S, O, Fall A, D, Gueye R, Diop A, Diatta K, Diop N, Ndiaye B, Diop Y, M, 2015 Etude de l'activité antioxydante des extraits des feuilles de Vitex Doniana (Verbenaceae). Int. J. Biol. Chem. Sci., 9(6):2676-2684.

Satapathy K, B, 2015. Medicinal Plant Diversity of Sukinda Valley in Jajpur district of Odisha. Int. J. Med. Plants, 108: 658-664.

Sharma H, Parihar L, Parihar $P, 2011$. Review on cancer and anticancerous properties of some medicinal plants. J. Med. Plant. Res., 5(10): 1818-1835.

Thomas S, K, George R, E, Kunjumon M, Thankamani V, I, 2016. Phytochemical Screening and TLC Profile of Fruits and Flowers of Alstonia venenata R. Br. Int. J. Pharm. Sci. Drug Res., 8(2): 117-120. 